\title{
Effects of different cytokines on immune responses of rainbow trout in a virus DNA vaccination model
}

\author{
Yongsheng Cao ${ }^{1,2}$, Qiya Zhang², Liming Xu${ }^{1}$, Shaowu Li ${ }^{1}$, Di Wang ${ }^{1}$, Jingzhuang \\ Zhao $^{1}$, Hongbai Liu ${ }^{1}$, Jian Feng ${ }^{3}$ and Tongyan Lu ${ }^{1}$ \\ ${ }^{1}$ Heilongjiang River Fishery Research Institute of Chinese Academy of Fishery Sciences, Harbin, China \\ 2 State Key Laboratory of Freshwater Ecology and Biotechnology, Institute of Hydrobiology, Chinese Academy of Sciences, \\ Wuhan, China \\ ${ }^{3}$ Benxi Agrimarine Company Limited, Benxi, China \\ Correspondence to: Tongyan Lu, email: Iutongyan@hotmail.com \\ Qiya Zhang, email: zhangay@ihb.ac.cn
}

Keywords: rainbow trout; cytokines; adjuvant; DNA vaccine; protection; Immune response; Immunology

Received: June 01,2017 Accepted: November 17, $2017 \quad$ Published: December 11, 2017

Copyright: Cao et al. This is an open-access article distributed under the terms of the Creative Commons Attribution License 3.0 (CC BY 3.0), which permits unrestricted use, distribution, and reproduction in any medium, provided the original author and source are credited.

\section{ABSTRACT}

Seven rainbow trout cytokine genes (interleukin (IL)-2, IL-8, IL-15, IL-17, IL$1 \beta$, intracellular interferon (iIFN) $1 a$, and IFN-Y2) were evaluated for their adjuvant effects on a DNA vaccine, called pG, containing the glycoprotein gene of infectious hematopoietic necrosis virus (IHNV). Distinct DNA constructs in expression plasmid pcDNA3.1 encoding a cytokine gene were generated. Immunofluorescence assays in rainbow trout gonadal cells demonstrated successful protein expression from all these constructs. Subsequently, fish were immunized with pG alone or together with a cytokine expression plasmid. Results showed that each cytokine plasmids at an appropriate dose showed notable effects on immune gene expression. IL-17 and IFN-Y2 can enhance early specific IgM response. All cytokines, except IL-8, can benefit initial neutralizing antibody (NAb) titers. At 35 days post immunization (dpi), NAb titers of fish immunized with pG and IL-2, iIFN1a, or IFN-y2 plasmids remained at high levels (1:160). NAb titers of fish immunized with pG alone decreased to 1:40. IL-8 or IL-1 $\beta$ can enhance antigen-specific proliferative T-cell responses at $14 \mathrm{dpi}$. At 28 dpi, coinjection of pG with IL-2, IL-8, IL-15, or IL-17 plasmids induced considerably stronger lymphocyte proliferation than that with injection of pG alone. All cytokine plasmids delivered with pG plasmid enhanced protection of trout against IHNVmediated mortality. These results indicate that the type and dose of trout cytokine genes injected into fish affect quality of immune response to DNA vaccination.

\section{INTRODUCTION}

Fish and aquaculture remain important sources of food, nutrition, income, and livelihood for many people worldwide. Rainbow trout (Oncorhynchus mykiss) is an important component of commercially valuable coldwater fish species in many countries [1]. However, rainbow trout production may suffer from severe losses due to infectious disease outbreaks $[2,3]$. Vaccine is the most appropriate method to prevent accidental effects of pathogenic microorganisms on rainbow trout $[4,5]$.
Inactivated or genetic engineering fish vaccines are developed for their biosafety, but they cannot elicit desired protective immune responses in some cases $[6$, 7]. Injection is currently a major immune route for fish vaccination, but it is laborious and inapplicable in larval fish, which are susceptible to pathogens [8]. According to the economic view, oral vaccination is the ideal route for vaccination programs, which require one or more booster immunizations [9]. Nevertheless, oral delivery antigen alone commonly results in low efficacy and short protection period [10]. Numerous studies proved that additional adjuvants in fish vaccines can enhance potency 
and longevity of specific immune responses to antigens $[11,12]$.

Cytokines are naturally low-molecular weight and secretory proteins that are produced in response to infection, and they are closely associated with immune system regulation [13]. In fish, the major cytokine families are present and expressed at the transcript level [14]. Fish cytokines are not properly used as vaccine adjuvants compared with their counterparts that are applied for the same purpose in mammals owing to deficient immunological roles [15]. Nonetheless, increasing numbers of studies reported that these molecules participate similarly to regulation of fish immune responses compared with those of mammals $[16,17]$. Type I interferon (IFN-I), interleukin (IL)-1 $\beta$, or IL-8 present conserved adjuvant effects on inactivated or DNA vaccine in fish [18-20].

To date, modulated immune responses by cytokines are not considerably understood compared with those of existing cytokine genes in fish. Abilities of various adjuvants to enhance immune responses induced by vaccines should be also determined and compared in a single system; results of such comparison will benefit elimination of impulsive interferences [21]. Infectious hematopoietic necrosis virus (IHNV) is a disease agent in salmonids [22]. In our previous work, we generated a DNA vaccine, named as $\mathrm{pG}$, with the glycoprotein $(\mathrm{G})$ gene of a Chinese IHNV isolate Sn1203 based on the pEE12.4 vector. However, $\mathrm{pG}$ fails to provide desired protective effects. In the present study, seven types of rainbow trout cytokines, namely, IL-2, IL-8, IL-15, IL17, IL-1 $\beta$, intracellular IFN1a (iIFN1a), and IFN- $\gamma 2$, were selected to investigate their effects on $\mathrm{pG}$ immune responses, including immune-related gene expression, serum-specific antibody level, neutralizing antibody (NAb) titer, lymphocyte proliferation, and protection. To our knowledge, this study is the first to collectively illustrate adjuvant effects of these cytokine genes of rainbow trout in vivo. This work will benefit screening of novel vaccine adjuvants for rainbow trout and provide valuable insights into trout immune responses.

\section{RESULTS}

\section{Plasmid construction, protein expression, and polyclonal antibody preparation}

Target DNA fragments were successfully amplified and cloned into pcDNA3.1 or pET32a plasmids. Polymerase chain reaction (PCR) and digestion proved that the recombinant plasmids contained cytokine DNA fragments (Figure 1A and 1B). Additionally, accuracies of fragments were confirmed by sequencing (data not shown). We named these eukaryotic expression plasmids as pIL-2, pIL-8, pIL-15, pIL-17, pIL-1 $\beta$, piIFN1a, and pIFN- $\gamma 2$.

After induction with isopropyl $\beta$-D-1thiogalactopyranoside (IPTG), Escherichia coli cells containing recombinant prokaryotic expression plasmids successfully expressed recombinant proteins, which were mostly located in inclusion bodies. In purification of Histagged proteins under denaturing conditions in the Qiagen handbook, target proteins were purified at 33.7, 30.8, 34 , and $46 \mathrm{kDa}$ with recombinant proteins of IL-2, IL-8, IL-15, and IL-1 $\beta$, respectively (Figure 2). Recombinant proteins of IL-17, iIFN1a, and IFN- $\gamma 2$ were prepared and characterized in our previous work [23-25].

After immunizing mice with purified proteins for four times, final titers of polyclonal antibodies against corresponding cytokines were determined by indirect enzyme-linked immunosorbent assay (ELISA). Results showed that titers of these polyclonal antibodies were all above 1:25600 (Figure 3). Thus, these polyclonal antibodies can be used for the following detection of expressions of cytokine genes in rainbow trout gonadal (RTG-2) cells.

\section{Expression of cytokine genes in RTG-2 cells}

RTG-2 cells were transfected with recombinant pcDNA3.1 plasmids containing cytokine genes. At 48 $\mathrm{h}$ post-transfection, cells were stained and incubated with the corresponding poly antiserums and fluorescein isothiocyanate (FITC)-conjugated anti-mouse $\mathrm{IgG}$ antibody. Specific fluorescence signal can be observed in cells transfected with pcDNA3.1-cytokines, whereas no specific fluorescence signal was observed in cells transfected with the pcDNA3.1 vector (Figure 4). Expression of pcDNA3.1-IL-17 in RTG-2 cells was confirmed in our previous work [23]. Results clearly show that the seven types of cytokine genes can be expressed from recombinant pcDNA3.1 plasmids in RTG-2 cells.

\section{Effect of cytokine plasmid coinjection on expressions of immune-related genes}

Fold changes in immune-related gene expression induced by three distinct doses of cytokine plasmid were analyzed with real-time PCR and compared (Figure 5). Results showed that, especially expressions of $\mathrm{Mx}$ and viperin, coinjection with any type of cytokine plasmid at a proper dose can enhance the majority of immune-related gene expressions compared with the injection with $\mathrm{pG}$ alone. Furthermore, these cytokines exert distinct effects on immune response. For example, IL-2 showed overall enhancements on the tested genes compared with those of other cytokines. IL-17 can enhance expressions of IgM and CD8 evidently compared with those of others. Diversity effects of one cytokine depend on injection 

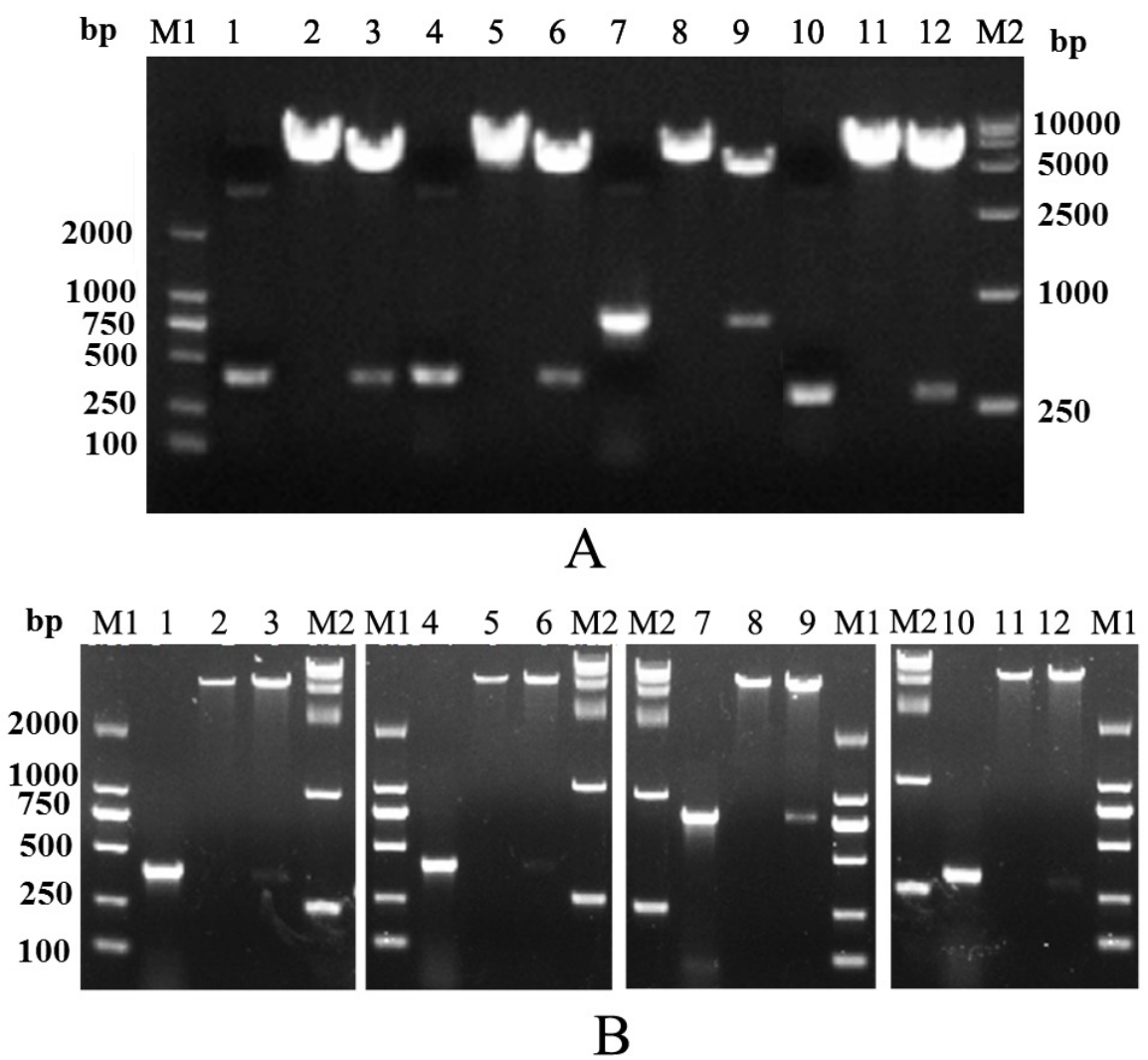

Figure 1: Construction of recombinant plasmids. (A) Identification of recombinant eukaryotic plasmids. (B) Identification of recombinant prokaryotic plasmids. M1, Trans 2K DNA marker; M2, Trans 15K DNA marker; lanes 1-3, PCR and digestion of recombinant plasmids containing IL-2 gene; lanes 4-6, PCR and digestion of recombinant plasmids containing IL-15 gene; lanes 7-9, PCR and digestion of recombinant plasmids containing IL- $1 \beta$ gene; lanes $10-12$, PCR and digestion of recombinant plasmids containing IL-8 gene.

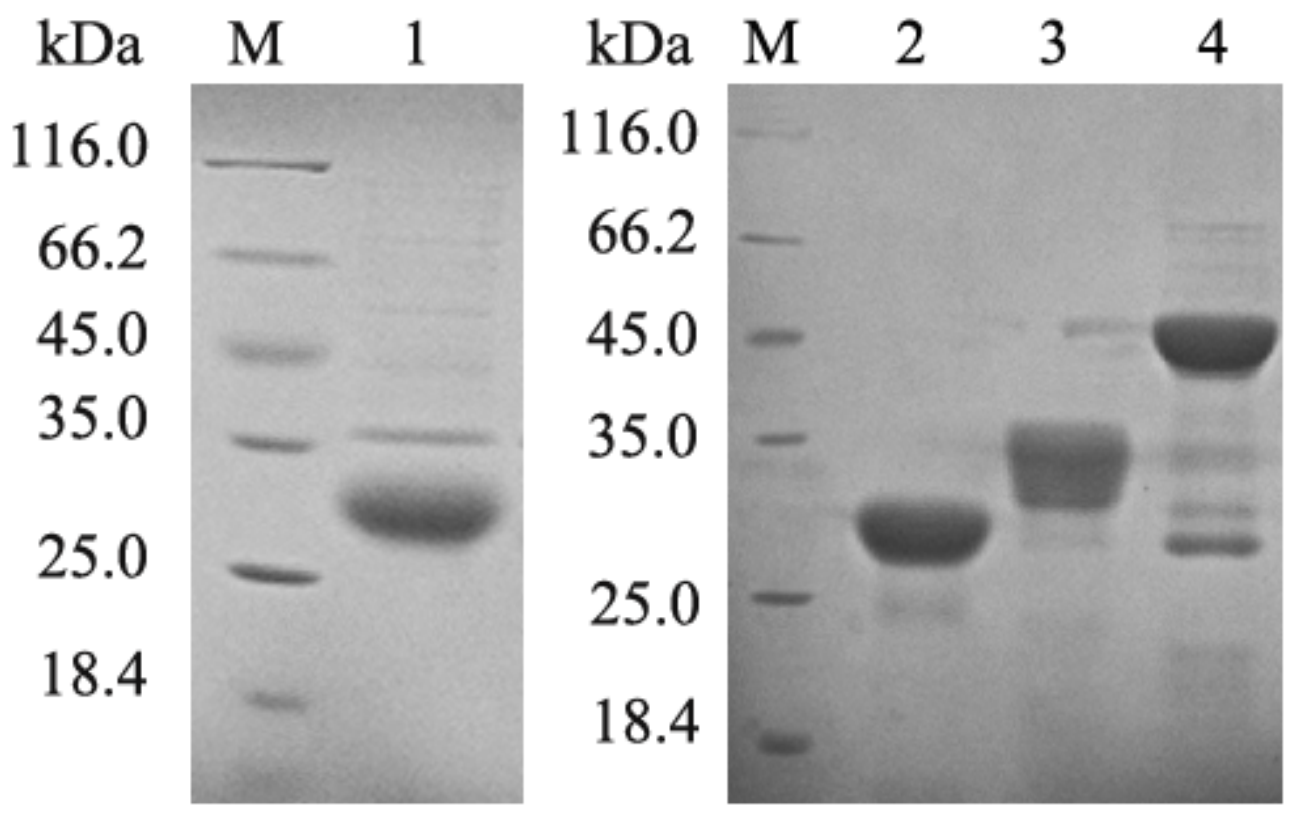

Figure 2: Expression and purification of recombinant proteins. M, unstained protein marker; lanes 1-6, purified recombinant IL-2, IL-8, IL-15, and IL-1 $\beta$ proteins, respectively. 
dose. Although any dose can enhance IgM expression, IL-1 $\beta$ can maximize this action at $2.5 \mu \mathrm{g}$ injection. IgT expression can only be modulated by IFN- $\gamma 2$ at $2.5 \mu \mathrm{g}$ injection. To guarantee maximum and general adjuvant effects of cytokines, cytokine plasmids were injected at a dose that can enhance the most immune-related gene expression induced by $\mathrm{pG}$ alone. In this study, IL-2, IL-8, IL-15, IL-17, IL-1 $\beta$, iIFN1a, and IFN- $\gamma 2$ plasmids were injected at $2.5,0.5,2.5,5.0,0.5,5.0$, or $2.5 \mu \mathrm{g}$ in the following immunization, respectively.

\section{Effect of cytokine plasmid coinjection on production of specific antibodies}

To evaluate the efficiency of cytokine adjuvants to enhance antibody response of rainbow trout against IHNV antigen, the fish were injected intramuscularly with $\mathrm{pG}$ alone or $\mathrm{pG}$ with cytokine plasmid or pcDNA3.1 plasmid. During each week of post immunization, sera were harvested, and specific IgM antibody was measured by ELISA using the recombinant IHNV-G protein as antigen (Figure 6). In general, levels of specific $\operatorname{IgM}$ in fish immunized with $\mathrm{pG}$ alone or together with cytokine plasmid were significantly higher than those receiving pcDNA3.1 $(\mathrm{P}<0.05)$. At 7 days post immunization (dpi), specific IgM levels induced by the combination of $\mathrm{pG}$ and IL-17 or IFN- $\gamma 2$ plasmid were significantly higher than that induced by $\mathrm{pG}$ alone $(\mathrm{P}<0.05)$. Furthermore, the combination of $\mathrm{pG}$ and IL-17 plasmid induced significantly higher specific $\operatorname{IgM}$ than $\mathrm{pG}$ alone at $14 \mathrm{dpi}(\mathrm{P}<0.05)$. However, with increasing IgM levels, no significant differences were observed in levels of specific IgM present in the fish immunized with $\mathrm{pG}$ and combination of $\mathrm{pG}$ and IL-8, IL-17, IL-1 $\beta$, or IFN- $\gamma 2$ plasmid. Unexpectedly, specific IgM levels in the remaining three adjuvant groups were significantly lower than those in the $\mathrm{pG}$ group $(\mathrm{P}<0.05)$. At $28 \mathrm{dpi}$, specific IgM reached the highest level, and no significant differences were observed among pG or adjuvant groups. Afterward, specific IgM levels decreased between 28 and 35 dpi. During this period, only the specific IgM level induced by the combination of $\mathrm{pG}$ and IL-2 plasmid was significantly lower than that induced by $\mathrm{pG}$ alone $(\mathrm{P}<0.05)$.

\section{Effect of cytokine plasmid coinjection on NAb titers}

Sera from three individual fish in all treated groups were collected and pooled. NAb titers were determined using plaque neutralization titer (PNT) procedure for IHNV (Table 2). At $7 \mathrm{dpi}$, only the combination of $\mathrm{pG}$ and IL-17, iIFN1a, or IFN- $\gamma 2$ plasmid induced positive NAb titers (1:40). At $14 \mathrm{dpi}$, the fish showed positive $\mathrm{NAb}$ titers, except for those injected with $\mathrm{pG}$ alone or co-injected with $\mathrm{pG}$ and IL-8 or IL-1 $\beta$ plasmid. At the following dpi, fish in experimental groups all displayed positive NAb titers with respective dynamics. NAb titers of fish treated with the combination of $\mathrm{pG}$ and IL-2 or

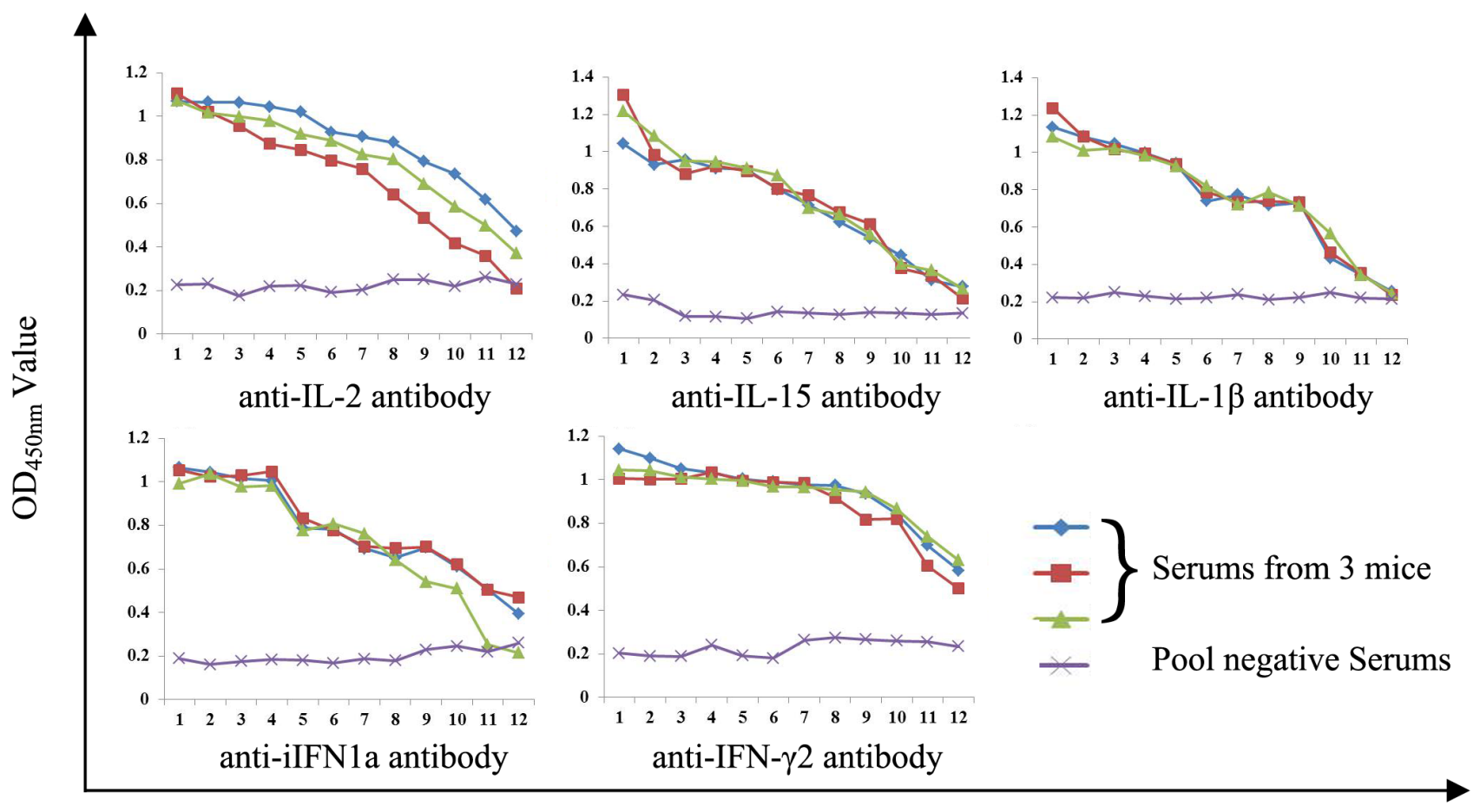

The 2-fold dilution series of serum (from $1: 100$ to $1: 204800$ )

Figure 3: Determination of antiserums titers by indirect ELISA. 
IL-15 plasmid reached the highest level at 28 dpi (1:160) and lasted until or decreased to 1:80 at $35 \mathrm{dpi}$. NAb titers of fish treated with the combination of $\mathrm{pG}$ and IL-8 or IL-1 $\beta$ plasmid also reached the highest level at $28 \mathrm{dpi}$ (1:80 or $1: 160)$ and decreased to $1: 40$ or $1: 80$ at $35 \mathrm{dpi}$. $\mathrm{NAb}$ titers of fish treated with the combination of $\mathrm{pG}$ and IL-17 plasmid reached the highest level at $21 \mathrm{dpi}$ (1:160), decreased at $28 \mathrm{dpi}$, and persisted until $35 \mathrm{dpi}$ (1:80). Additionally, NAb titers of fish treated with the combination of $\mathrm{pG}$ and iIFN1a or IFN- $\gamma 2$ plasmid reached the highest level at 21 or $14 \mathrm{dpi}$ and lasted until $35 \mathrm{dpi}$ (1:160). NAb titers of fish treated with $\mathrm{pG}$ alone reached the highest level at $21 \mathrm{dpi}(1: 160)$ and decreased to 1:80 and 1:40 at 28 and $35 \mathrm{dpi}$, respectively. No NAbs were detected in sera from pcDNA3.1-treated fish.

\section{Effect of cytokine plasmid coinjection on lymphocyte proliferation}

At 14 and 28 dpi, lymphocytes from three fish in each experiment group were cultured with phytohaemagglutinin (PHA) or recombinant IHNV-G protein. Effects of PHA and specific antigen on lymphocyte proliferation were determined (Figure 7). At 14 dpi, PHA exhibited significant stimulatory effects on cells from fish co-immunized with pG and IL-2, IL-8, IL-15, or iIFN1a plasmids compared with fish immunized with $\mathrm{pG}$ alone or $\mathrm{pG}$ and IL-17, IL-1 $\beta$, or IFN- $\gamma 2$ plasmid $(\mathrm{P}<0.05)$. Additionally, lymphocytes from fish co-injected with $\mathrm{pG}$ and IL-8 or IL- $1 \beta$ plasmid proliferated significantly under the stimulation of recombinant IHNV-G protein compared with those from fish in other groups $(\mathrm{P}<0.05)$. However, at $28 \mathrm{dpi}$, both PHA and recombinant IHNV-G protein showed significant stimulatory effects on cells from fish co-immunized with pG and IL-2, IL-8, IL-15, or IL-17 plasmid compared with those of fish immunized with pG alone or $\mathrm{pG}$ and IL-1 $\beta$, iIFN1a, or IFN- $\gamma 2$ plasmid $(\mathrm{P}<0.05)$.

\section{Cytokines increase protection of pG against IHNV challenge}

To assess whether cytokine may increase protective effects of pG against IHNV infection, immunized fish were challenged with IHNV at 28 dpi, and accumulated fish survivals were determined. At 14 days after injection of IHNV, fish injected with pG alone showed significantly higher protection (43.3\% survival) than those injected with pcDNA3.1 (13.3\% survival). Coinjection with any cytokine plasmid resulted in significant protection. Among the cytokine plasmids used, IL-2, IL-17, iIFN1a, and IFN- $\gamma 2$ plasmid strongly enhanced protection $(80 \%$, $76.7 \%, 73.3 \%$, and $76.7 \%$ survival, respectively). Survival resulting from coinjection of $\mathrm{pG}$ with IL- 8 and IL- $1 \beta$ plasmids reached $66.7 \%$ and $60 \%$, respectively. IL-15 displayed weak adjuvant effects on protection $(56.7 \%$ survival) (Figure 8).
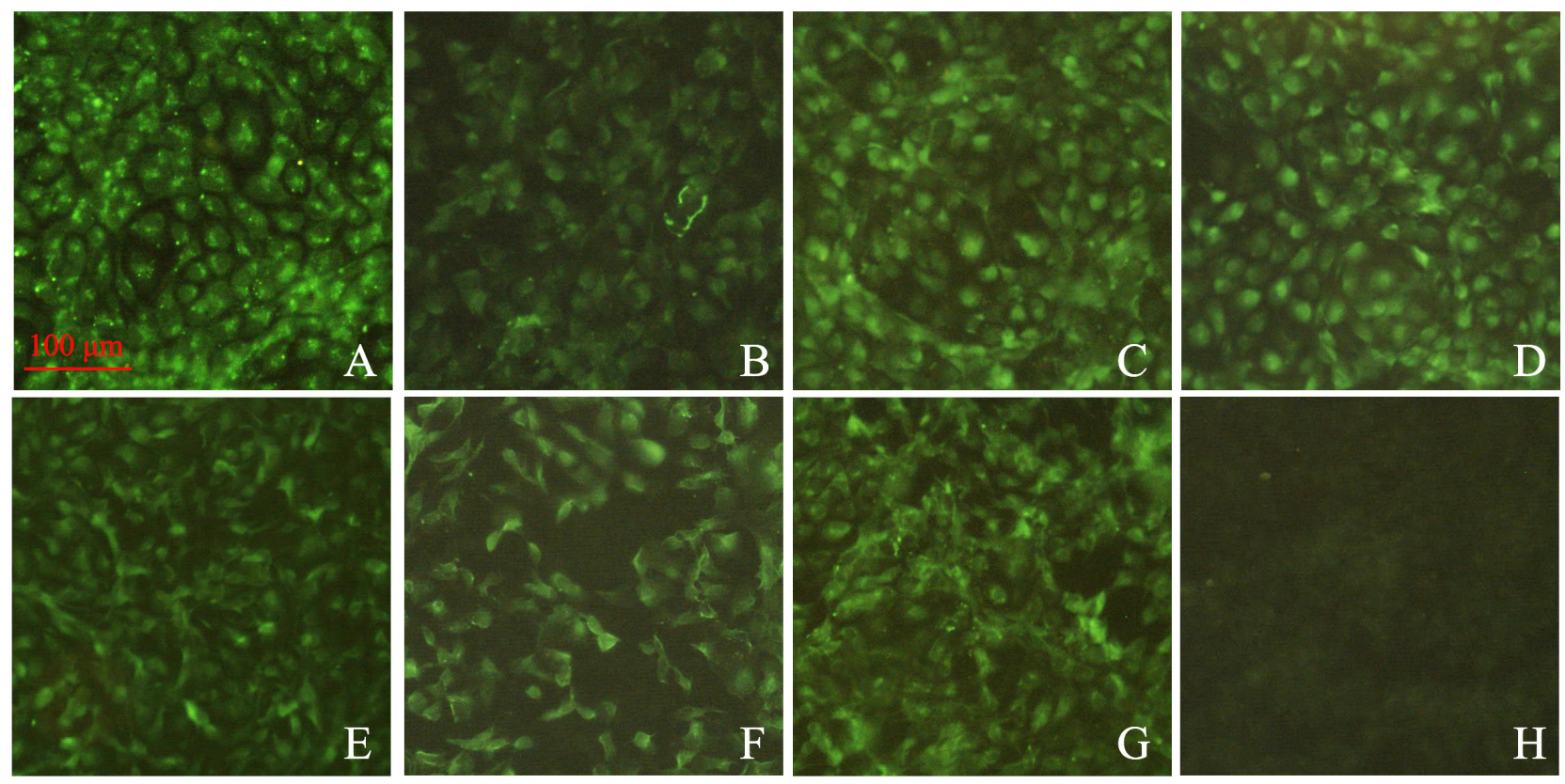

Figure 4: Immunofluorescence analysis of RTG-2 cells transfected with recombinant plasmids containing the cytokine gene. A-G. Cells were transfected with pcDNA3.1-IL-2, IL-8, IL-15, IL-17, IL-1 $\beta$, iIFN1a, and IFN- $\gamma 2$, respectively. Subsequently, transient expressions of proteins within cells were detected with the corresponding polyclonal antibodies. H. Cells were transfected with pcDNA3.1 empty vector, which served as negative control. The green signals reflect positive expressions of proteins of interest. 


\section{DISCUSSION}

Among genetic engineering vaccines, DNA vaccines containing protective antigens in recombinant plasmids are relatively efficient in inducing protective immune response against fish rhabdoviruses in salmons [26]. However, DNA vaccines against infectious pancreatic necrosis virus, infectious salmon anemia virus, or lymphocystis disease virus are less effective in protection [27]. Additionally, many aspects, such as alternative routes of immunization that allow mass or fry vaccination, should still be optimized with adjuvants $[10,28]$. Therefore, rational fish vaccines should be designed; these vaccines must include a combination of antigens and tailored adjuvant systems that induce effective immune responses against specific pathogens without adverse side effects [15].

Adjuvants should be used at a proper dose because low dose of some adjuvants can provide similar

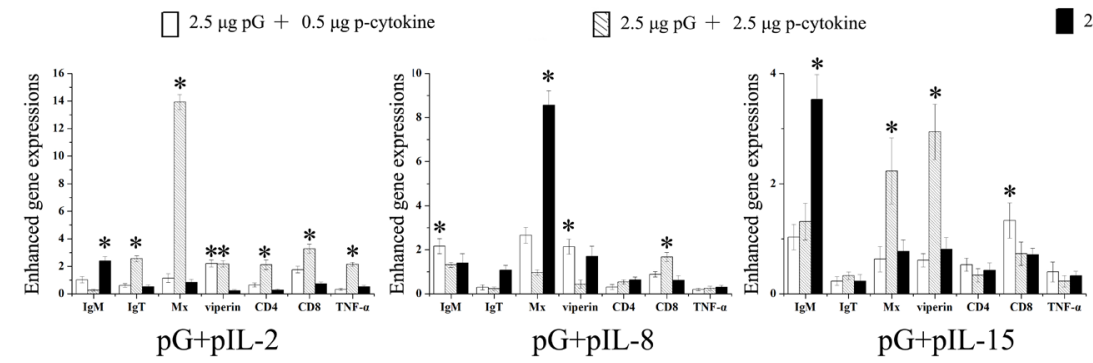

$2.5 \mu \mathrm{g} \mathrm{pG}+5 \mu \mathrm{g}$ p-cytokine
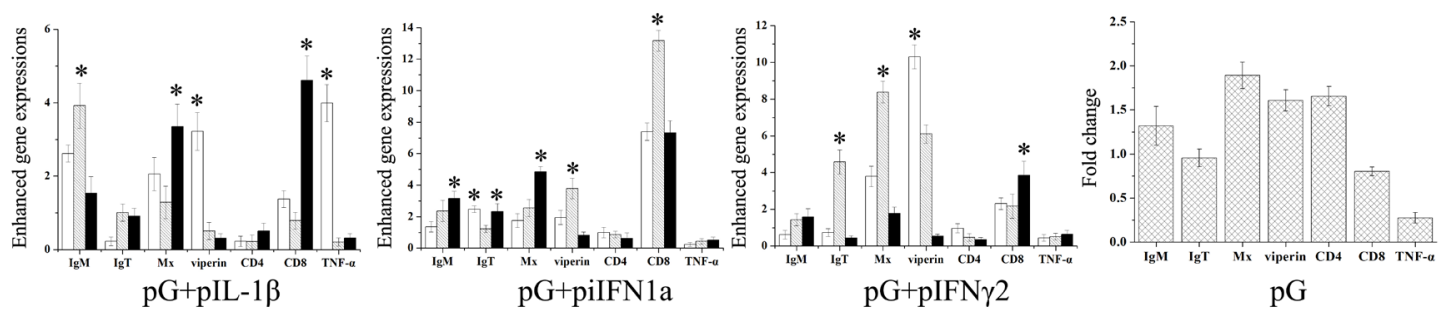

Figure 5: Enhanced immune-related gene expression in spleens of rainbow trout. Five fish were intraperitoneally injected with $\mathrm{pG}$ alone or $\mathrm{pG}$ with cytokine adjuvants $(0.5,2.5$, or $5 \mu \mathrm{g})$. At $3 \mathrm{dpi}$, expressions of immune-related genes in the spleen were analyzed with real-time PCR. Fold changes in immune gene expression in adjuvant groups were calculated relative to that in pG group. *, $\mathrm{P}<0.05$.

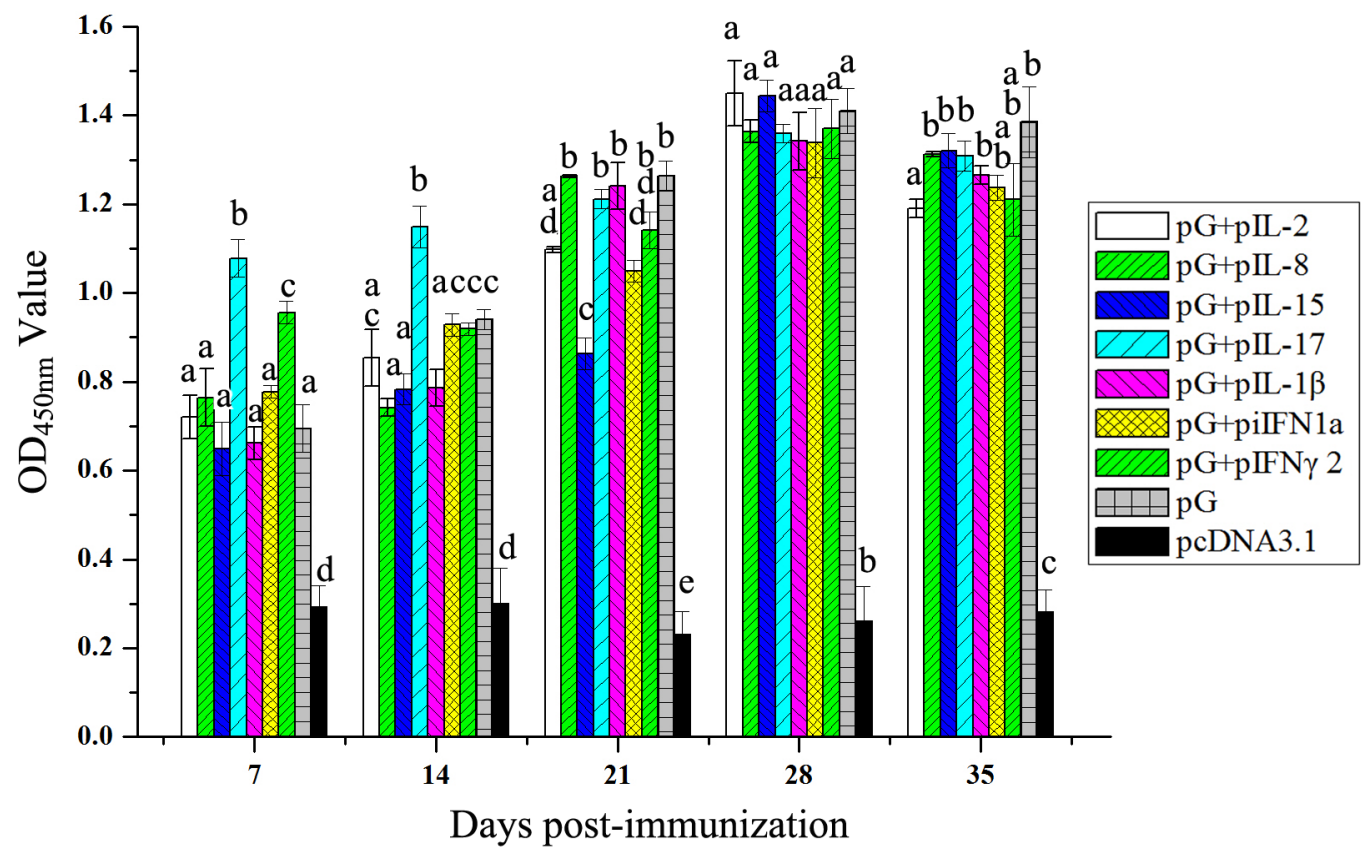

Figure 6: Anti-infectious IHNV-G IgM levels in fish treated with pG and cytokine DNA. Fish were immunized with pG (2.5 $\mu \mathrm{g}$ ) alone or pG with IL-2 plasmid ( $2.5 \mu \mathrm{g})$, IL-8 plasmid $(0.5 \mu \mathrm{g})$, IL-15 plasmid $(5 \mu \mathrm{g})$, IL-17 plasmid ( $2.5 \mu \mathrm{g})$, IL-1 13 plasmid $(0.5 \mu \mathrm{g})$, iIFN1a plasmid $(5 \mu \mathrm{g})$, IFN- $\gamma 2$ plasmid $(2.5 \mu \mathrm{g})$, or cDNA3.1 plasmid. Serum samples were collected each week of post immunization until 35 dpi. Anti-IHNV-G IgM antibodies were detected with indirect ELISA. Different letters indicate significant differences $(\mathrm{P}<0.05)$. 
enhancement effects [29]; at high doses, adjuvants promote opposite, tolerogenic responses [30]. Fish cytokines are parts of the animals' natural responses to microbial infection or vaccination [31]. Nevertheless, only few studies have given considerable attention to antigen/cytokine adjuvant ratio in fish vaccine. Immune relevant gene expression analyses are widely recognized as essential for determination of fish immune responses. Gene expression induced with antigens at different doses of seven different trout cytokine plasmids were investigated for the first time. Different doses of cytokine plasmids showed remarkable adjuvant effects on induction of immune genes. Fish vaccine preparation commonly includes construction of expression plasmid containing antigens and cytokine gene or mixture of antigens with equal volumes of cytokine [32, 33]. According to our results, IL-2, IL-15, and IFN- $\gamma 2$ are suitable as adjuvants when used in this manner. Nonetheless, IL-17 and iIFN1a
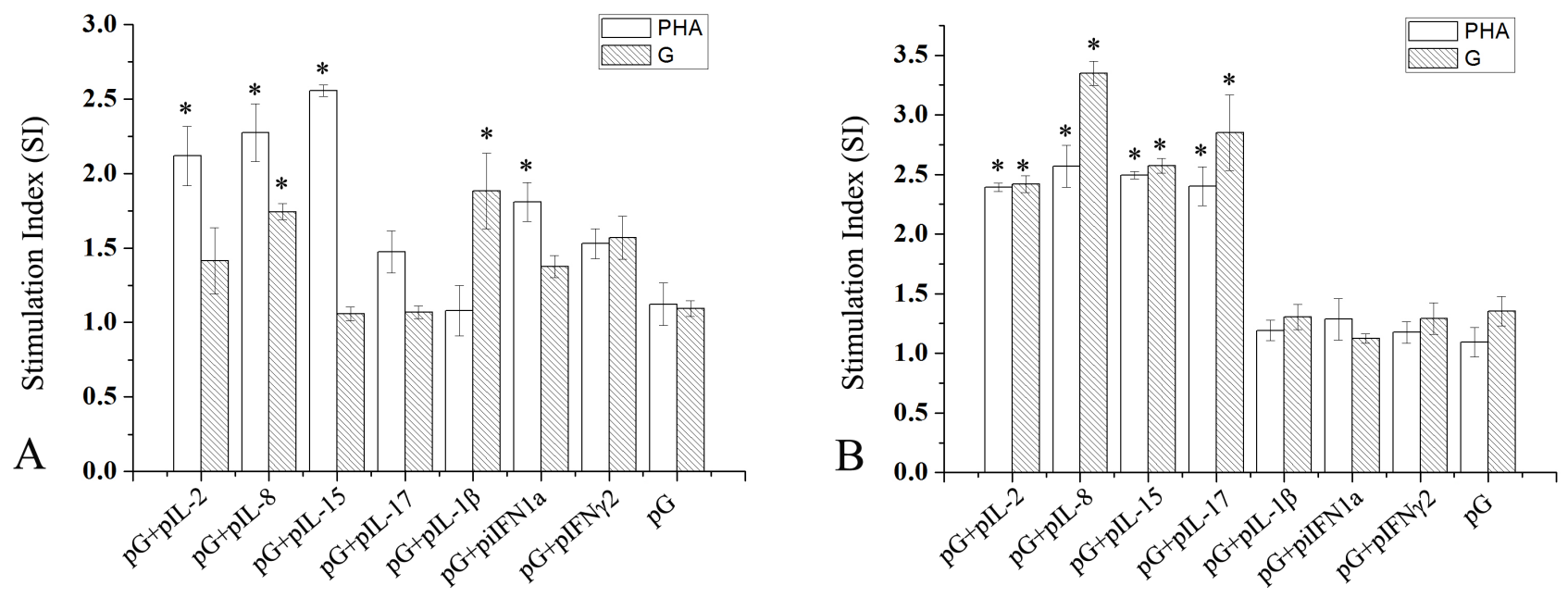

Figure 7: Proliferative T-cell responses in spleens of immunized fish. Fish were immunized with pG alone or together with cytokine plasmid or pcDNA3.1 plasmid. At 14 and 28 dpi (A and B), leukocytes from spleens of three rainbow trout from each experimental group were isolated and cultured under PHA or recombinant $\mathrm{G}$ protein stimulation. Stimulation indices between each group were compared. $*, \mathrm{P}<0.05$.

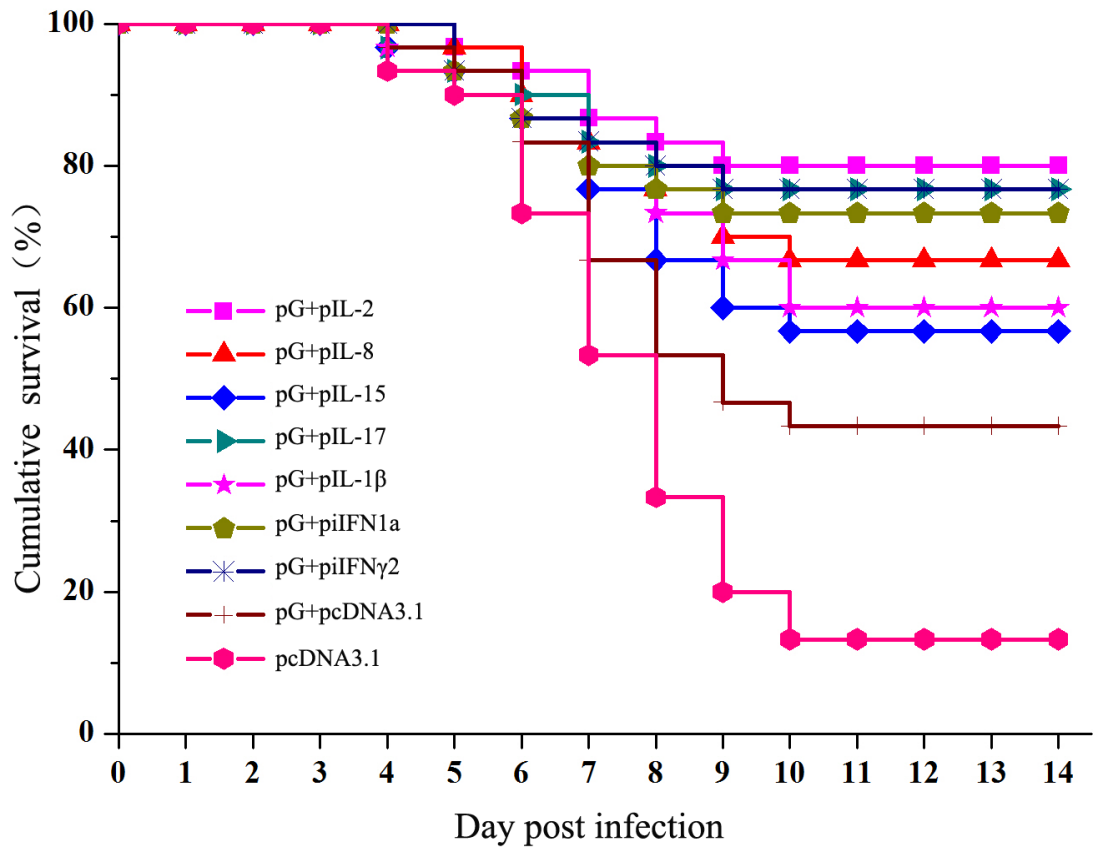

Figure 8: Survival plots for vaccinated trout after being challenged with IHNV. Fish were injected with intramuscular injection of $\mathrm{pG}$ alone or the combination of $\mathrm{pG}$ and cytokine plasmids. At $28 \mathrm{dpi}$, fish were challenged by intraperitoneal injection with 300 pfu of IHNV. 
may function significantly at high doses. Although the knowledge on trout IL-17 remains limited, dose-response studies on human IL-17-induced IL-1 $\beta$ and tumor necrosis factor (TNF)- $\alpha$ release showed that IL-1 $\beta$ and TNF- $\alpha$ release increases with IL-17 concentration, and an effective concentration is necessary to increase their release [34]. iIFN1a is a member of trout IFN-a, and it serves as a functional iIFN that performs novel defense mechanism to combat viral infections [35]. This distinct function characteristic may have resulted in high dose need of iIFN1a to stimulate efficient immune response. IL-8 of rainbow trout and other fish can modulate early immune responses against infections $[33,36]$. Our results indicate that low IL-8 concentration may provide better stimulus than at high concentrations. IL-1 $\beta$ also exerted significant effects on immune response at low doses, agreeing with previous results showing that the specific IgG induced with low dose of recombinant mouse IL- $1 \beta$ is comparable to that induced with normal dose [29].

An effective immune response to immunization should include the innate and adaptive immune subsystems [37]. Innate immunity plays important roles in the first defense and a crucial part in initiation and subsequent direction of adaptive immune responses [38]. IHNV G protein is a good inducer of IFN-I [39]. In our study, cytokine plasmids further up-regulated expressions of antiviral proteins (Mx and viperin). Both our previous study and other's work proved that antiviral abilities of trout IFNs depend on dose and kinetics of antiviral state $[24,40]$. Hence, cytokine plasmids may enhance efficiency and longevity of nonspecific protection before the initial adaptive immune response takes effect. However, challenge experiments in early stages of immunization should be performed to ascertain this hypothesis.

Long-term stimulation of humoral and cellmediated arms of the adaptive system must be provided by immunization to combat virus infection. Mammalian cytokines are immune potentiators that target the innate immune system [37]. Based on bioactivities of many trout cytokines, future studies should examine the possibility of improving adaptive immunity with various trout cytokines. To analyze the onset of humoral response, rainbow trout was immunized with combinations of $\mathrm{pG}$ and cytokine plasmids. Only IL-17 and IFN- $\gamma 2$ can significantly enhance early specific IgM response. All these cytokine genes exerted no contribution to the peak level of specific IgM induced by $\mathrm{pG}$. This phenomenon was also observed in a former study. Two immunizations of DNA vaccine in combination with any of immunomodulator expression vectors (IL-2, IL-12, IL-15, or granulocyte-macrophage colony-stimulating factor) exhibit no significant alteration on serum antibody response observed in immunized mice; however, a third immunization results in further increase in specific antibody titer in these mice [41]. Enhanced immunization with the combination of $\mathrm{pG}$ and cytokine plasmid may have caused this significance.
Given that the NAbs are both sufficient and necessary for protection against viral infections [42], we evaluated whether cytokine plasmids cause differences in NAb production. All the tested cytokines, except IL-8 and IL$1 \beta$, can enhance early response and longevity of NAbs. Thus, effects of cytokine gene injection on humoral response induced by $\mathrm{pG}$ mainly relies on NAb production. Coinjection of IL-8 plasmid with DNA vaccine modulates cytokine response of rainbow trout mainly by promoting the increase in proinflammatory cytokines (IL-1 $\beta$ and TNF- $\alpha$ ) [36]. Our results indicate that IL- 8 was less effective in inducing NAb response, whereas IL- $1 \beta$ exerted no effect on early production of NAbs. Nonetheless, fish IL-8 enhances antibody response in DNA vaccination against bacterial infection [20]. Considering that limited available knowledge about adjuvant effects of fish IL-8 in virus DNA vaccination can be used for comparison, difficulty arises from determining causes resulting in less effects of IL-8 trout on humoral immunity.

In addition to humoral immunity, accumulating evidence showed that cell-mediated immunity and/or local immunity play important roles in pathogen protection achieved by vaccines, particularly mucosal vaccination in fish [43]. Additionally, several important virus pathogens can cause acute diseases and high mortality and result in persistent infections in salmons [44, 45]. The surviving fish, which may become virus carriers without showing symptoms, potentially pose a threat to the health of naïve fish. Cell-mediated responses play an important role in clearance of virus, but viruses may evade cellular immunity and persist in vivo [46]. Data demonstrated that trout IL-2, IL-8, IL-15, IL-1 $\beta$, or IL-17 all showed conserved abilities to enhance antigen-specific proliferative T-cell responses [47-50]. IL-8 coinjection can also induce considerably strong lymphocyte proliferation in the two test points. IL-1 $\beta$ only functions at early time points. Coinjection of IL-2, IL-15, and IL-17 induces delayed strong lymphocyte proliferation.

Importantly, a correlation was observed between cytokine plasmid enhancement of challenge protection and adaptive immune response. Observed cytokines also enhanced protection by their distinct actions. IL-2 and IL-17 enhanced the majority of tested immune gene expressions, NAb production, longevity, and cellmediated immunity. Hence, these cytokines can improve protection the most significantly. Previous studies showed that trout IL-8 injection can elicit a marked total number of leukocytes present in the peritoneal cavity [51]. Coinjection of IL-8 with the glycoprotein gene from viral hemorrhagic septicemia virus can also modulate cytokine response in rainbow trout [36]. However, actual adjuvant effects of trout IL-8 on protection are still unknown. According to our results, trout IL-8 can enhance protection mainly through cell-mediated immunity. iIFN1a and IFN- $\gamma 2$ also exerted limited effects on cellmediated immune response, but both improved protective 
Table 1: Primers used for cloning, expression and qRT-PCR of genes in this study

\begin{tabular}{|c|c|c|}
\hline Primer name & Primer sequences (5' to $\left.3^{\prime}\right)$ & Application \\
\hline IL-2 BamH I-F & GGATCCAACCCAATTCCCAGACTCCT & \multirow{2}{*}{$\begin{array}{l}\text { prokaryotic expression } \\
\text { plasmid construction }\end{array}$} \\
\hline IL-2 Hind III-R & AAGCTTTTATGAACTTAGACGCTTTGC & \\
\hline IL-2 EcoR I-F & GAATTCGCCACCATGAACCCAATTCCCAGACTCCT & \multirow{2}{*}{$\begin{array}{l}\text { eukaryotic expression } \\
\text { plasmid construction }\end{array}$} \\
\hline IL-2 Xho I-R & CTCGAGTCATGAACTTAGACGCTTTGC & \\
\hline IL-8 BamH I-F & GGATCCATGAGCATCAGAATGTCAGCCAG & \multirow{2}{*}{$\begin{array}{l}\text { prokaryotic expression } \\
\text { plasmid construction }\end{array}$} \\
\hline IL-8 Hind III-R & AAGCTTTTATTTGTTGTTGGCCAGCATCT & \\
\hline IL-8 EcoR I-F & GAATTCGCCACCATGAGCATCAGAATGTCAGCCAG & \multirow{2}{*}{$\begin{array}{l}\text { eukaryotic expression } \\
\text { plasmid construction }\end{array}$} \\
\hline IL-8 Xho I-R & CTCGAGTCATTTGTTGTTGGCCAGCATCT & \\
\hline IL-15 BamH I-F & GGATCCGCTGAAACACACGGGATGA & \multirow{2}{*}{$\begin{array}{l}\text { prokaryotic expression } \\
\text { plasmid construction }\end{array}$} \\
\hline IL-15 Hind III-R & AAGCTTTTAACTGACAGTTTGCCCTATTC & \\
\hline IL-15 EcoR I-F & GAATTCGCCACCATGGCTGAAACACACGGGATGA & \multirow{2}{*}{$\begin{array}{l}\text { eukaryotic expression } \\
\text { plasmid construction }\end{array}$} \\
\hline IL-15 Xho I-R & CTCGAGTCAACTGACAGTTTGCCCTATTC & \\
\hline IL-17 EcoR I-F & GAATTCGCCACCATGGAGCTCAAAAGCAACGT & \multirow{2}{*}{$\begin{array}{l}\text { eukaryotic expression } \\
\text { plasmid construction }\end{array}$} \\
\hline IL-17 Xho I-R & CTCGAGTCAAGTAGTCCTTGCCCA & \\
\hline IL-1 $\beta$ EcoR I-F & GAATTCATGGATTTTGAGTCAAACTAC & \multirow{2}{*}{$\begin{array}{l}\text { prokaryotic expression } \\
\text { plasmid construction }\end{array}$} \\
\hline IL-1 $\beta$ Hind III-R & AAGCTTTTAGTTGTGGCGCTGGATGGT & \\
\hline IL-1 $\beta$ EcoR I-F & GAATTCGCCACCATGGATTTTGAGTCAAACTAC & \multirow{2}{*}{$\begin{array}{l}\text { eukaryotic expression } \\
\text { plasmid construction }\end{array}$} \\
\hline IL-1 $\beta$ Xho I-R & CTCGAGTCAGTTGTGGCGCTGGATGGT & \\
\hline iIFN1a EcoR I-F & GAATTCGCCACCATGCAGAGCGTGTGTCATTG & \multirow{2}{*}{$\begin{array}{l}\text { eukaryotic expression } \\
\text { plasmid construction }\end{array}$} \\
\hline iIFN1a Xho I-R & CTCGAGTCAGTACATCTGTGCCGCAA & \\
\hline IFN- $\gamma 2$ EcoR I-F & GAATTCGCCACCATGGCTCAGTACACATCAATTAAC & \multirow{2}{*}{$\begin{array}{l}\text { eukaryotic expression } \\
\text { plasmid construction }\end{array}$} \\
\hline IFN- $\gamma 2$ Xho I-R & CTCGAGTCACATGATGTGTGATTTGAG & \\
\hline $\operatorname{IgM~F}$ & CAAACCGGTGGAAGCTACAT & \multirow{2}{*}{ real time PCR } \\
\hline IgM R & AGACGGCTGCTGCAGATATT & \\
\hline IgT F & AACATCACCTGGCACATCAA & \multirow{2}{*}{ real time PCR } \\
\hline IgT R & TTCAGGTTGCCCTTTGATTC & \\
\hline Mx F & AGCGTCTGGCTGATCAGATT & \multirow{2}{*}{ real time PCR } \\
\hline Mx R & AGCTGCTCGATGTTGTCCTT & \\
\hline Viperin F & GTGTTCCAGTGTCTGCTGATCGAT & \multirow{2}{*}{ real time PCR } \\
\hline Viperin R & TGATGCTGCTGTGCCTTTCC & \\
\hline CD4 F & CATTAGCCTGGGTGGTCAAT & \multirow{2}{*}{ real time PCR } \\
\hline CD4 R & CССТTTCTTTGACAGGGAGA & \\
\hline CD8 F & GACTGCTGGCTGTGGCTTCC & \multirow{2}{*}{ real time PCR } \\
\hline CD8 R & CCCCGGAGCTGCCATTCT & \\
\hline $\mathrm{TNF}-\alpha \mathrm{F}$ & TCTTACCGCTGACACAGTGC & \multirow{2}{*}{ real time PCR } \\
\hline TNF- $\alpha$ R & AGAAGCCTGGCTGTAAACGA & \\
\hline$\beta$-Actin F & GCCGGCCGCGACCTCACAGACTAC & \multirow{2}{*}{ real time PCR } \\
\hline$\beta$-Actin R & CGGCCGTGGTGGTGAAGCTGTAAC & \\
\hline
\end{tabular}

Underlined nucleotides are restriction sites, bold shown as Kozak consensus sequence.

efficiency similar to IL-2 and IL-17. Injection with fish IFN plasmid alone can provide protection to some extent [32]. Our previous studies also confirmed antiviral activities of recombinant iIFN1a and IFN- $\gamma 2$ proteins against IHNV, whereas protection decreases within 3 dpi $[24,25]$. Notably, the challenge was performed at $28 \mathrm{dpi}$. Therefore, we believed that positive effects on protection were not due to their antiviral activities but enhanced NAb response. Nevertheless, adjuvant effect of IL-15 was less clear in challenge experiments because weak modulation of protection showed no good agreement with its comparable stimulated effects. Nonetheless, all cytokines efficiently improve $\mathrm{pG}$ DNA vaccination of trout against IHNV-mediated mortality.

In this study, seven types of trout cytokines were evaluated as adjuvants because of their abilities to enhance antigen-specific immune responses following injection delivery. Results showed that these cytokines exerted positive effects on a variety of immune responses and protective efficiency. Additionally, their modulations on immune outcomes depended on cytokine types and were associated with the used dose (at least in terms of 
Table 2: The detection of NAb titers

\begin{tabular}{|l|l|l|l|l|l|}
\hline $\begin{array}{l}\text { Dpi } \\
\text { Groups }\end{array}$ & 7 & 14 & 21 & 28 & 35 \\
\hline pG+pIL-2 & $1: 20$ & $1: 40$ & $1: 80$ & $1: 160$ & $1: 160$ \\
\hline pG+pIL-8 & $1: 20$ & $1: 20$ & $1: 40$ & $1: 80$ & $1: 40$ \\
\hline pG+pIL-15 & $<1: 20$ & $1: 40$ & $1: 80$ & $1: 160$ & $1: 80$ \\
\hline pG+pIL-17 & $1: 40$ & $1: 40$ & $1: 160$ & $1: 80$ & $1: 80$ \\
\hline pG+pIL-1 $\beta$ & $1: 20$ & $1: 20$ & $1: 20$ & $1: 160$ & $1: 80$ \\
\hline pG+piIFN1a & $1: 40$ & $1: 80$ & $1: 160$ & $1: 160$ & $1: 160$ \\
\hline pG+pIFN- $\gamma 2$ & $1: 40$ & $1: 160$ & $1: 160$ & $1: 160$ & $1: 160$ \\
\hline pG & $1: 20$ & $1: 20$ & $1: 160$ & $1: 80$ & $1: 40$ \\
\hline pcDNA3.1 plasmid & $<1: 20$ & $<1: 20$ & $<1: 20$ & $<1: 20$ & $<1: 20$ \\
\hline
\end{tabular}

Fish were immunized with $\mathrm{pG}$ alone or together with cytokine plasmid or pcDNA3.1. Serums of three fish from each group were collected and pooled after each week of post immunization. Titers $<1: 20$ were defined as negative.

different immune relevant gene expressions). However, further studies are required to confirm the responses discussed, especially possible variances existing between the combination with other types of antigen and delivery methods. Nevertheless, our study support that trout cytokines are novel adjuvants, which can also enhance certain immune responses in vaccines.

\section{MATERIALS AND METHODS}

\section{Ethics statement}

Investigations were conducted in accordance with the ethical standards and the Guidelines of European Union Council Directive 2010/63/EU (http://ec.europa.eu/ environment/chemicals/lab_animals/legislation_en.htm) for the protection of animals used for scientific purposes. This study was also approved by the Committee of the Ethics on Animal Care and Experiments at Heilongjiang River Fishery Research Institute of Chinese Academy of Fishery Sciences.

\section{Fish, virus strain, plasmid, and reagent}

Healthy rainbow trout (approximately $10 \mathrm{~g}$ ) were maintained in aerated fiberglass tanks supplied with a continuous flow of recirculating freshwater at $15^{\circ} \mathrm{C}$. Sn1203 strain of IHN virus (GenBank NO.: KC660147.1) was isolated from rainbow trout with clinical symptoms of IHN. Stock titer was $3 \times 10^{6}$ plaque forming units $(\mathrm{pfu}) /$ ml. RTG-2 (ATCC CCL-55) cells were cultured in Eagle's minimal essential medium supplemented with $10 \%$ fetal bovine serum (FBS, Gibco).

Based on the sequence of glycoprotein gene of IHNV Sn1203, a pair of primers (5'GAATTCATGGACACCATGATCACCACTCCG-3' and
5'-GGATCCTCAGGACCGGTTTGCCAGGTGAT-3'; underlined sequences are restriction sites for enzymes EcoRI and BamHI) were designed to amplify the glycoprotein gene. cDNA was prepared as PCR template from IHNV. Subsequently, the glycoprotein gene of IHNV Sn1203 was cloned into pEE12.4 plasmid and designated as pG. Recombinant $\mathrm{G}$ protein of IHNV was generated in prokaryotic expression system, and its immunogenicity was also confirmed [52]. The anti-IgM antibody was generated based on recombinant truncated IgM of rainbow trout in our previous work [53].

\section{Cloning and construction of plasmids}

According to sequences of IL-2, IL-8, IL15, IL-17, IL-1 $\beta$, iIFN1a, and IFN- $\gamma 2$ (Gen Bank NO. NM_001164065.1, AJ279069.1, AJ555868.1, NM_001124619.2, NM_001124347.2, FJ184370.1, and FM864345.1), primers were designed to amplify their corresponding genes (Table 1). cDNA was prepared as PCR template according to our previous method [24]. PCR products were analyzed by agarose gel electrophoresis and purified using TIANgel Midi Purification Kit (Tiangen, China). Purified DNA fragments and pET32a or pcDNA3.1 vector were digested and linked by T4 DNA ligase to construct recombinant plasmids. Positive clones were identified by colony PCR using the primers indicated above and digested with restriction enzymes. Plasmids from positive clones were extracted using GeneJET Plasmid Miniprep Kit (Thermo Scientific, USA) and subsequent DNA sequencing. Recombinant eukaryotic expression plasmids were extracted using GeneJET EndoFree Plasmid Maxiprep Kit (Thermo Scientific, USA), quantified, and stored at $-20{ }^{\circ} \mathrm{C}$ carefully. 


\section{Protein expression, purification, and refolding}

Prokaryotic expression plasmids were transformed into Rosetta (DE3) PLysS cells and induced with addition of IPTG $(1 \mathrm{mM})$ when the culture reached between 0.4 and 0.6 at $\mathrm{OD}_{600}$. Cells were harvested by centrifuging the culture at $8000 \mathrm{~g}$ for $5 \mathrm{~min}$ at $4 \mathrm{~h}$ after induction. Cell pellets were lysed by sonication. The presence of fusion proteins in supernatant and the pellet containing inclusion bodies were analyzed by $12 \%$ sodium dodecyl sulfate polyacrylamide gel electrophoresis (SDS-PAGE). Inclusion bodies were washed twice with $2 \mathrm{M}$ urea solutions and dissolved in $8 \mathrm{M}$ urea solutions. Soluble fractions were purified using protein purification with $\mathrm{Ni}-$ NTA protein purification system (Qiagen, USA). Purified proteins were refolded by gradient dialysis from $6 \mathrm{M}$ urea solutions to PBS containing $5 \%$ glycerol at $4{ }^{\circ} \mathrm{C}$ and analyzed by $12 \%$ SDS-PAGE. Finally, refolded proteins were quantified and stored at $-80{ }^{\circ} \mathrm{C}$.

\section{Preparation of polyclonal antibodies}

Anti-IL-17 antibodies were produced in our previous work [23]. Twenty-four female BALB/c mice (7 weeks old) were divided into six groups. Prior to immunization, three mice were bled by the tail vein. Afterward, mice from each group were immunized intraperitoneally with $100 \mu \mathrm{g}$ of refolded proteins mixed with complete freund's adjuvant (CFA) individually. After 1 week, the mice were subsequently boosted thrice with $50 \mu \mathrm{g}$ of proteins mixed with incomplete freund's adjuvant (IFA) at two-week intervals. Blood samples were obtained from mice tail vein at 1 week after each immunization. Sera were isolated to determine antibody titers by ELISA. At 1 week after the last injection, mice were killed to collect the sera, which were stored at $-20^{\circ} \mathrm{C}$. Antiserum titers were determined by indirect ELISA.

\section{Indirect IFA}

An indirect IFA was performed to confirm expression of constructs in RTG-2 cells.. RTG-2 cells were cultured in six-well plates until cell density was $60 \%-80 \%$ confluent. Cells were transfected with $2 \mu \mathrm{g}$ of plasmids per well using Lipofectamine ${ }^{\circledR} 2000$ Transfection Reagent (Invitrogen, USA). Cells that were transfected with pcDNA3.1 empty vector served as negative controls. At $48 \mathrm{~h}$ after transfection, cells were fixed with $2 \%$ paraformaldehyde for $12 \mathrm{~min}$ and washed with PBS buffer. Subsequently, cells were incubated with corresponding polyclonal antibodies at $1: 100$ dilutions at $37^{\circ} \mathrm{C}$ for $1 \mathrm{~h}$. The control group was incubated with pool polyclonal antibodies. After three washes with PBS, cells were incubated with FITC-conjugated Goat Anti-Mouse IgG
(Abcam, USA) at $37^{\circ} \mathrm{C}$ for $1 \mathrm{~h}$. After four washes with PBS, cells were observed under fluorescent microscope.

\section{Real-time PCR detection}

A total of 115 fish were divided into 23 groups, anesthetized with eugenol, and injected i.m. with $2.5 \mu \mathrm{g}$ of $\mathrm{pG}$ alone or $\mathrm{pG}$ with cytokine plasmids $(0.5,2.5$, or 5 $\mu \mathrm{g})$. The fish injected with pcDNA3.1 served as negative control. At 3 dpi, spleen tissues from three fish from each experimental group were collected and stored in liquid nitrogen.

Total RNA of samples was extracted with an SV Total RNA Isolation System (Promega, USA) and quantified. cDNA was synthetized from $1 \mu \mathrm{g}$ of total RNA with a PrimeScript ${ }^{\mathrm{TM}}$ RT Master Mix. Relative quantification real-time PCR was performed on an Applied Biosystems 7500 according to manufacturer's instructions for SYBR ${ }^{\circledR}$ Premix Ex Taq $^{\text {TM }}$ II (Tli RNaseH Plus). Primers were referenced from publications $[54,55]$ and are listed in Table 1. Expression level of $\beta$-actin served as internal control. Relative expression level was obtained by normalizing the expression of the target gene to that of $\beta$-actin. All PCR reactions were performed in triplicate. Relative expression ratio $(\mathrm{R})$ was calculated and compared with those of untreated samples using $2^{-\Delta \Delta C}$ method [56]. Fold changes in immune gene expression in adjuvant groups were calculated relative to that in $\mathrm{pG}$ group.

\section{Vaccination, sample collection, and challenge}

According to immune gene expressions of different combinations of $\mathrm{pG}$ and cytokine adjuvants, injection dose of p-cytokines was confirmed. A total of 540 fish were divided into nine groups, anesthetized with eugenol, and injected intramuscularly with $\mathrm{pG}$ and $\mathrm{pG}$ with cytokine plasmid and pcDNA3.1 plasmid. Serum samples from three individuals in each group were prepared and stored at $-20{ }^{\circ} \mathrm{C}$ at each week of post immunization until 35 dpi. At 14 and 28 dpi, leukocytes from spleens of three rainbow trout from each experimental group were isolated using Ficoll-Paque PLUS (1.077 and $1.05 \mathrm{~g} / \mathrm{ml}$, GE Healthcare, Sweden) according to a previous method [57]. At 28 dpi, the remaining 30 healthy fish from each group were challenged with $50 \mu 1$ of IHNV (300 pfu) by intraperitoneal injection. The fish were monitored daily for clinical signs of the disease, and dead fish were removed. Survival of each group was recorded daily for 14 days, and cumulative percent survival was determined.

\section{Detection of specific IgM by indirect ELISA}

The 96-well ELISA plates were coated with recombinant $\mathrm{G}$ protein at $0.1 \mu \mathrm{g}$ in carbonate buffer at $\mathrm{pH}$ 
9.6 with $100 \mu \mathrm{l}$ per well and incubated overnight at $4{ }^{\circ} \mathrm{C}$. After three washes with $0.05 \%$ Tween 20 in PBS buffer (PBST), the plates were blocked with PBST containing $1 \%$ gelatin (Sigma-Aldrich) at $37{ }^{\circ} \mathrm{C}$ for $1 \mathrm{~h}$. After four washes with PBST, the wells were incubated with $100 \mu \mathrm{l}$ of serum samples with different dilutions for $1 \mathrm{~h}$. Wells were washed again with PBST for four times and were incubated with $100 \mu \mathrm{l}$ of anti-IgM antibody at 1:250 dilution for $1 \mathrm{~h}$. After another four washes with PBST, the wells were incubated with horseradish peroxidaseconjugated goat antirabbit IgG antibody (Abcam, USA) at $37{ }^{\circ} \mathrm{C}$ for $0.5 \mathrm{~h}$. After the final washes, tetramethyl benzidine solution was added at $70 \mu \mathrm{l}$ per well. After 12 min, the reaction was stopped with addition of $\mathrm{H}_{2} \mathrm{SO}_{4}(1$ M). Absorbance was measured at $450 \mathrm{~nm}$ using a plate reader (Molecular Devices).

\section{NAb titers}

PNT procedure for IHNV was described previously. Briefly, three serum samples from each experiment group were pooled and heat-inactivated at $45{ }^{\circ} \mathrm{C}$ for $30 \mathrm{~min}$. Afterward, the two-fold dilution series of serum (1:20 to $1: 320$ ) was incubated with an equal volume of IHNV stock for $30 \mathrm{~min}$ at $18{ }^{\circ} \mathrm{C}$. Samples were added to RTG-2 cells, which were pretreated with $7 \%$ polyethylene glycol and adsorbed after $1 \mathrm{~h}$. Cells were overlaid with a medium containing 4\% FBS and 1\% methyl cellulose medium (Sigma, USA). When cytopathic effects were observed, cells were fixed with formalin and stained with crystal violet. The highest dilution that resulted in $50 \%$ reduction in that of negative control was considered the NAb titer.

\section{Lymphocyte proliferation assay}

Leukocyte suspension was added in triplicate to 96-well plates. Experimental groups were incubated with the medium containing $2 \mu \mathrm{g} / \mathrm{ml}$ recombinant $\mathrm{G}$ protein. A total of $5 \mu \mathrm{g} / \mathrm{ml}$ PHA (Sigma, USA) was added to cultures, which were used as positive control. Negative control cells were incubated with the medium. Cell proliferation was assessed using a water-soluble tetrazolium salt-1 Cell Proliferation and Cytotoxicity Assay Kit (Beyotime, China) according to the protocol manual. Results were presented as stimulation index, which was calculated as the ratio of $A 450$ of stimulated to that of unstimulated proliferation.

\section{Statistical analysis}

Comparisons of gene expression between adjuvant groups and the vaccine group were performed using oneway ANOVA. Student's t-test was also used to compare some paired samples. Differences were considered statistically significant at $\mathrm{P}<0.05$.

\section{CONFLICTS OF INTEREST}

The authors declare no conflict of interest.

\section{FUNDING}

This work was funded by the Central-level Nonprofit Scientific Research Institutes Special Funds (HSY201702M), China Postdoctoral Science Foundation Funded Project (2016M602395), and the State Key Laboratory of Freshwater Ecology and Biotechnology (2017FB03). We would like to express our sincere appreciation to the anonymous reviewers for their insightful comments.

\section{REFERENCES}

1. Food and Agriculture Organization (FAO). The State of World Fisheries and Aquaculture 2016. Contributing to Food Security and Nutrition for All. Rome, Italy. 2016; 200 pp.

2. Cieslak M, Mikkelsen SS, Skall HF, Baud M, Diserens N, Engelsma MY, Haenen OL, Mousakhani S, Panzarin V, Wahli T, Olesen NJ, Schutze H. Phylogeny of the Viral Hemorrhagic Septicemia Virus in European Aquaculture. Plos One. 2016; 11: e164475.

3. Kumar G, Menanteau-Ledouble S, Saleh M, El-Matbouli M. Yersinia ruckeri, the causative agent of enteric redmouth disease in fish. Vet Res. 2015; 46: 103.

4. Rouxel RN, Tafalla C, Merour E, Leal E, Biacchesi S, Bremont M. Attenuated Infectious Hematopoietic Necrosis Virus with Rearranged Gene Order as Potential Vaccine. J Virol. 2016; 90: 10857-10866.

5. Chen ZY, Lei XY, Zhang QY. The antiviral defense mechanisms in mandarin fish induced by DNA vaccination against a rhabdovirus. Vet Microbiol. 2012; 157: 264-275.

6. Miquel A, Muller I, Ferrer P, Valenzuela PD, Burzio LO. Immunoresponse of Coho salmon immunized with a gene expression library from Piscirickettsia salmonis. Biol Res. 2003; 36: 313-323.

7. Nunez-Ortiz N, Pascoli F, Picchietti S, Buonocore F, Bernini C, Toson M, Scapigliati G, Toffan A. A formalininactivated immunogen against viral encephalopathy and retinopathy (VER) disease in European sea bass (Dicentrarchus labrax): immunological and protection effects. Vet Res. 2016; 47: 89.

8. Plant KP, Lapatra SE. Advances in fish vaccine delivery. Dev Comp Immunol. 2011; 35: 1256-1262.

9. Muktar Y, Tesfaye S, Tesfaye B. Present Status and Future Prospects of Fish Vaccination: A Review. J Veterinar Sci Technol. 2016; 2: 299.

10. Embregts CW, Forlenza M. Oral vaccination of fish: 
Lessons from humans and veterinary species. Dev Comp Immunol. 2016; 64: 118-137.

11. Cobo LC, Makhutu M, Lumsdon AE, Thompson KD, Jung R, Kloas W, Knopf K. The adjuvant effect of low frequency ultrasound when applied with an inactivated Aeromonas salmonicida vaccine to rainbow trout (Oncorhynchus mykiss). Vaccine. 2015; 33: 1369-1374.

12. Liu X, Zhang H, Jiao C, Liu Q, Zhang Y, Xiao J. Flagellin enhances the immunoprotection of formalin-inactivated Edwardsiella tarda vaccine in turbot. Vaccine. 2017; 35: 369-374.

13. Tovey MG, Lallemand C. Adjuvant activity of cytokines. Methods Mol Biol. 2010; 626: 287-309.

14. Zou J, Secombes CJ. The Function of Fish Cytokines. Biology. 2016; 5: 23.

15. Tafalla C, Bogwald J, Dalmo RA. Adjuvants and immunostimulants in fish vaccines: current knowledge and future perspectives. Fish Shellfish Immunol. 2013; 35: 1740-1750.

16. Zhang YB, Gui JF. Molecular regulation of interferon antiviral response in fish. Dev Comp Immunol. 2012; 38: 193-202.

17. Zhu R, Wang J, Lei XY, Gui JF, Zhang QY. Evidence for Paralichthys olivaceus IFITM1 antiviral effect by impeding viral entry into target cells. Fish Shellfish Immunol. 2013; 35: 918-926.

18. Robertsen B, Chang CJ, Bratland L. IFN-adjuvanted DNA vaccine against infectious salmon anemia virus: Antibody kinetics and longevity of IFN expression. Fish Shellfish Immunol. 2016; 54: 328-332.

19. Yin Z, Kwang J. Carp interleukin-1 beta in the role of an immuno-adjuvant. Fish Shellfish Immunol. 2000; 10: 375378.

20. Wang E, Long B, Wang K, Wang J, He Y, Wang X, Yang Q, Liu T, Chen D, Geng Y, Huang X, Ouyang P, Lai W. Interleukin-8 holds promise to serve as a molecular adjuvant in DNA vaccination model against Streptococcus iniae infection in fish. Oncotarget. 2016; 7:83938-50. https://doi. org/10.18632/oncotarget.13728.

21. Min W, Lillehoj HS, Burnside J, Weining KC, Staeheli P, Zhu JJ. Adjuvant effects of IL-1beta, IL-2, IL-8, IL-15, IFN-alpha, IFN-gamma TGF-beta4 and lymphotactin on DNA vaccination against Eimeria acervulina. Vaccine. 2001; 20: 267-274.

22. Dixon P, Paley R, Alegria-Moran R, Oidtmann B. Epidemiological characteristics of infectious hematopoietic necrosis virus (IHNV): a review. Vet Res. 2016; 47: 63.

23. Cao YS, Xu LM, Zhao JZ, Liu M, Lu TY. Preparation and identification of polyclonal antibody of IL-17 in rainbow trout (Oncorhynchus mykiss). Chinese Journal of Fisheries. 2016; 29: 1-5.

24. Cao Y, Xu L, LaPatra SE, Zhao J, Liu M, Liu H, Lu T, Zhang Q. The kinetics and protection of the antiviral state induced by recombinant iIFN1a in rainbow trout against infectious hematopoietic necrosis virus. Mol Immunol. 2016; 76: 55-61.

25. Cao YS, Xu LM, Zhao JZ, Liu M, Zhang QY, Lu TY. Prokaryotic expression and antiviral activity against infectious hematopoietic necrosis virus (IHNV) of the recombinant IFN- $\gamma 2$ of rainbow trout (Oncorhynchus mykiss). Journal of Fisheries of China. 2016; 40: 15861594.

26. Lorenzen N, LaPatra SE. DNA vaccines for aquacultured fish. Rev Sci Tech. 2005; 24: 201-213.

27. Evensen O, Leong JA. DNA vaccines against viral diseases of farmed fish. Fish Shellfish Immunol. 2013; 35: 17511758.

28. Zhao JZ, Xu LM, Liu M, Cao YS, LaPatra SE, Yin JS, Liu HB, Lu TY. Preliminary study of an oral vaccine against infectious hematopoietic necrosis virus using improved yeast surface display technology. Mol Immunol. 2017; 85: 196-204.

29. Kayamuro H, Yoshioka Y, Abe Y, Arita S, Katayama K, Nomura T, Yoshikawa T, Kubota-Koketsu R, Ikuta $\mathrm{K}$, Okamoto S, Mori Y, Kunisawa J, Kiyono H, et al. Interleukin-1 family cytokines as mucosal vaccine adjuvants for induction of protective immunity against influenza virus. J Virol. 2010; 84: 12703-12712.

30. Volpi C, Fallarino F, Pallotta MT, Bianchi R, Vacca C, Belladonna ML, Orabona C, De Luca A, Boon L, Romani L, Grohmann U, Puccetti P. High doses of CpG oligodeoxynucleotides stimulate a tolerogenic TLR9-TRIF pathway. Nat Commun. 2013; 4: 1852.

31. Wang T, Secombes CJ. The cytokine networks of adaptive immunity in fish. Fish Shellfish Immunol. 2013; 35: 1703 1718.

32. Chang CJ, Sun B, Robertsen B. Adjuvant activity of fish type I interferon shown in a virus DNA vaccination model. Vaccine. 2015; 33: 2442-2448.

33. Wang E, Wang J, Long B, Wang K, He Y, Yang Q, Chen D, Geng Y, Huang X, Ouyang P, Lai W. Molecular cloning, expression and the adjuvant effects of interleukin-8 of channel catfish (Ictalurus Punctatus) against Streptococcus iniae. Sci Rep. 2016; 6: 29310.

34. Jovanovic DV, Di Battista JA, Martel-Pelletier J, Jolicoeur FC, He Y, Zhang M, Mineau F, Pelletier JP. IL-17 stimulates the production and expression of proinflammatory cytokines, IL-beta and TNF-alpha, by human macrophages. J Immunol. 1998; 160: 3513-3521.

35. Chang MX, Zou J, Nie P, Huang B, Yu Z, Collet B, Secombes CJ. Intracellular interferons in fish: a unique means to combat viral infection. Plos Pathog. 2013; 9: e1003736.

36. Jimenez N, Coll J, Salguero FJ, Tafalla C. Co-injection of interleukin 8 with the glycoprotein gene from viral haemorrhagic septicemia virus (VHSV) modulates the cytokine response in rainbow trout (Oncorhynchus mykiss). Vaccine. 2006; 24: 5615-5626. 
37. Clem AS. Fundamentals of vaccine immunology. J Glob Infect Dis. 2011; 3: 73-78.

38. Langevin C, Aleksejeva E, Passoni G, Palha N, Levraud JP, Boudinot $\mathrm{P}$. The antiviral innate immune response in fish: evolution and conservation of the IFN system. J Mol Biol. 2013; 425: 4904-4920

39. Kim CH, Johnson MC, Drennan JD, Simon BE, Thomann E, Leong JA. DNA vaccines encoding viral glycoproteins induce nonspecific immunity and Mx protein synthesis in fish. J Virol. 2000; 74: 7048-7054.

40. Ooi EL, Verjan N, Haraguchi I, Oshima T, Kondo H, Hirono I, Aoki T, Kiyono H, Yuki Y. Innate immunomodulation with recombinant interferon-alpha enhances resistance of rainbow trout (Oncorhynchus mykiss) to infectious hematopoietic necrosis virus. Dev Comp Immunol. 2008; 32: 1211-1220.

41. Moore AC, Kong WP, Chakrabarti BK, Nabel GJ. Effects of antigen and genetic adjuvants on immune responses to human immunodeficiency virus DNA vaccines in mice. $\mathrm{J}$ Virol. 2002; 76: 243-250.

42. Klasse PJ. Neutralization of Virus Infectivity by Antibodies: Old Problems in New Perspectives. Adv Biol. 2014; 2014: 157895.

43. Salinas I. The Mucosal Immune System of Teleost Fish. Biology (Basel). 2015; 4: 525-539.

44. Ballesteros NA, Rodriguez SS, Perez-Prieto SI. Immune responses to oral pcDNA-VP2 vaccine in relation to infectious pancreatic necrosis virus carrier state in rainbow trout (Oncorhynchus mykiss). Vet Immunol Immunopathol. 2015; 165: 127-137.

45. Muller A, Sutherland BJ, Koop BF, Johnson SC, Garver KA. Infectious hematopoietic necrosis virus (IHNV) persistence in Sockeye Salmon: influence on brain transcriptome and subsequent response to the viral mimic poly (I:C). Bmc Genomics. 2015; 16: 634.

46. Purcell MK, Laing KJ, Winton JR. Immunity to fish rhabdoviruses. Viruses. 2012; 4: 140-166.

47. Blattman JN, Grayson JM, Wherry EJ, Kaech SM, Smith KA, Ahmed R. Therapeutic use of IL-2 to enhance antiviral T-cell responses in vivo. Nat Med. 2003; 9: 540-547.
48. Zhao Y, Cheng K, Wu Y, Peng XC, Chen Y, Tan BX, Ge J, Dong H, Wei M, Gao F, Su JM, Hou JM, Liu JY. Interleukin-15 enhances T-cell responses by stimulation with dendritic cells. Clin Transl Oncol. 2011; 13: 275-280.

49. Lin Y, Slight SR, Khader SA. Th17 cytokines and vaccineinduced immunity. Semin Immunopathol. 2010; 32: 79-90.

50. Staats HF, Ennis FA Jr. IL-1 is an effective adjuvant for mucosal and systemic immune responses when coadministered with protein immunogens. J Immunol. 1999; 162: 6141-6147.

51. Harun NO, Zou J, Zhang YA, Nie P, Secombes CJ. The biological effects of rainbow trout (Oncorhynchus mykiss) recombinant interleukin-8. Dev Comp Immunol. 2008; 32: 673-681.

52. Xu LM, Liu HB, Yin JS, Lu TY. [Prokaryotic expression and immunogenicity analysis of glycoprotein from infectious hematopoietic necrosis virus]. [Article in Chinese]. Bing Du Xue Bao. 2013; 29:529-34.

53. Zhao JZ, Xu LM, Liu M, Cao YS, Yin JS, Liu HB, Lu TY. Expression and rabbit antisera preparation of IgM heavy chain gene in rainbow trout (Oncorhynchus mykiss). Journal of Fisheries of China. 2014; 38: 1175-1181.

54. Evenhuis JP, Cleveland BM. Modulation of rainbow trout (Oncorhynchus mykiss) intestinal immune gene expression following bacterial challenge. Vet Immunol Immunopathol. 2012; 146: 8-17.

55. Penaranda MM, Purcell MK, Kurath G. Differential virulence mechanisms of infectious hematopoietic necrosis virus in rainbow trout (Oncorhynchus mykiss) include host entry and virus replication kinetics. J Gen Virol. 2009; 90: 2172-2182.

56. Livak KJ, Schmittgen TD. Analysis of relative gene expression data using real-time quantitative PCR and the 2(-Delta Delta C(T)) Method. Methods. 2001; 25: 402-408.

57. Lunden $\mathrm{T}$, Bylund $\mathrm{G}$. The influence of in vitro and in vivo exposure to antibiotics on mitogen-induced proliferation of lymphoid cells in rainbow trout (Oncorhynchus mykiss). Fish Shellfish Immunol. 2000; 10: 395-404. 